\title{
Mismatch repair deficiency/microsatellite instability-high as a predictor for anti-PD-1/ PD-L1 immunotherapy efficacy
}

\author{
Pengfei Zhao ${ }^{1 \dagger}, \mathrm{Li} \mathrm{Li}^{2+}$, Xiaoyue Jiang ${ }^{2}$ and Qin $\mathrm{Li}^{2^{*}}$
}

\begin{abstract}
Immunotherapies have led to substantial changes in cancer treatment and have been a persistently popular topic in cancer research because they tremendously improve the efficacy of treatment and survival of individuals with various cancer types. However, only a small proportion of patients are sensitive to immunotherapy, and specific biomarkers are urgently needed to separate responders from nonresponders. Mismatch repair pathways play a vital role in identifying and repairing mismatched bases during DNA replication and genetic recombination in normal and cancer cells. Defects in DNA mismatch repair proteins and subsequent microsatellite instability-high lead to the accumulation of mutation loads in cancer-related genes and the generation of neoantigens, which stimulate the anti-tumor immune response of the host. Mismatch repair deficiency/microsatellite instability-high represents a good prognosis in early colorectal cancer settings without adjuvant treatment and a poor prognosis in patients with metastasis. Several clinical trials have demonstrated that mismatch repair deficiency or microsatellite instabilityhigh is significantly associated with long-term immunotherapy-related responses and better prognosis in colorectal and noncolorectal malignancies treated with immune checkpoint inhibitors. To date, the anti-programmed cell death-1 inhibitor pembrolizumab has been approved for mismatch repair deficiency/microsatellite instability-high refractory or metastatic solid tumors, and nivolumab has been approved for colorectal cancer patients with mismatch repair deficiency/microsatellite instability-high. This is the first time in the history of cancer therapy that the same biomarker has been used to guide immune therapy regardless of tumor type. This review summarizes the features of mismatch repair deficiency/microsatellite instability-high, its relationship with programmed death-ligand 1/programmed cell death-1, and the recent advances in predicting immunotherapy efficacy.
\end{abstract}

Keywords: Tumor, Mismatch repair deficiency, Microsatellite instability, Immunotherapy, Immune checkpoint blockade

In recent years, immunotherapy has become the focus of the revamped cancer therapeutic paradigm. Immunotherapy has brought amazing and long-lasting tumor remission for several common solid malignancies and refractory malignancies [1-6]. Nonetheless, the extensive clinical application of immunotherapies has been limited because some tumors show relatively poor efficacy and low response rates $[1,2]$. Therefore, biomarkers are urgently needed to distinguish the sensitive patients and to

\footnotetext{
*Correspondence: oncologistinbj@163.com

†Pengfei Zhao and Li Li contributed equally to this work.

${ }^{2}$ Department of Oncology, Beijing Friendship Hospital, Capital Medical

University, Beijing 100050, China

Full list of author information is available at the end of the article
}

predict therapeutic response. Ample evidence supports programmed death-ligand 1 (PD-L1) or programmed cell death-1 (PD-1) expression, tumor mutational burden (TMB), numbers of tumor-infiltrating lymphocytes (TILs), peripheral blood lymphocyte count, mismatch repair deficiency (dMMR), and microsatellite instabilityhigh (MSI-H) as predictive biomarkers that guide the clinical application of immune checkpoint blockade (ICB) therapies [7]. Among many indicators, dMMR and MSI-H show unique advantages. Tumors with dMMR or MSI-H are sensitive to ICB, particularly to PD- 1 and PD-L1 inhibitors. It is worth emphasizing that dMMR or MSI-H could identify responders regardless of tumor location and tumor type, that is, they have the ability to

(c) The Author(s). 2019 Open Access This article is distributed under the terms of the Creative Commons Attribution 4.0 International License (http://creativecommons.org/licenses/by/4.0/), which permits unrestricted use, distribution, and 
guide different tumor immunotherapies in the same manner. Subsequently, the US Food and Drug Administration (FDA) approved the indication of ICB for all $\mathrm{dMMR} / \mathrm{MSI}-\mathrm{H}$ solid tumors [8]. In this review, we elaborate on the expression of MMR/MSI in multiple tumors, the predictive value of MMR/MSI-H in ICB treatment, the relationship between MSI-H and other predictor markers.

\section{Mismatch repair proficiency/deficiency and microsatellite instability}

The DNA mismatch repair (MMR) system, which exists extensively in organisms from prokaryotes to eukaryotes, is a highly conserved repair mechanism in cellular evolution. MMR was first found as a causative germline alteration in patients with Lynch syndrome in 1993 and was termed a microsatellite [9-12]. The MMR system plays key roles in identifying and repairing mismatched nucleotides during genetic recombination or as a result of damage caused by external physical or chemical insults. MMR guarantees genomic integrity and stability and avoids insertions and deletions of abnormal DNA at microsatellites. The MMR system comprises a series of specific DNA mismatch repair enzymes and is usually dependent on four key genes: mutL homologue 1 (MLH1), postmeiotic segregation increased 2 (PMS2), mutS homologue 2 (MSH2), and mutS 6 (MSH6). MLH1, PMS2, MSH2, and MSH6 proteins are mainly detected through immunohistochemical methods in the clinic. MSH2/MSH6 heterodimers are responsible for binding to the initial DNA mismatched base errors (including single-base mismatch and incorrect insertion or deletion loop mismatch) by conformational changes, and MLH1/PMS2 heterodimers are in charge of the excision and synthesis of corrected DNA chains in the mismatch site (see Fig. 1a). If one or more proteins are not expressed or are dysfunctional, the status is called dMMR; otherwise, the status is considered mismatch repair proficient (pMMR). MLH1 and MSH2 play pivotal roles in the process of MMR by dimerizing and interacting with MSH6 and PMS2. The dysfunction of MLH1 or MSH2 leads to the inactivation of MLH1/PMS2 or MSH2/MSH6 and the degradation of PMS2 or MSH6 (see Fig. 1b). Lynch syndrome is a common hereditary disease that is characterized by germline mutations in $M M R$ genes [13]. Lynch syndrome is associated with

\section{A}

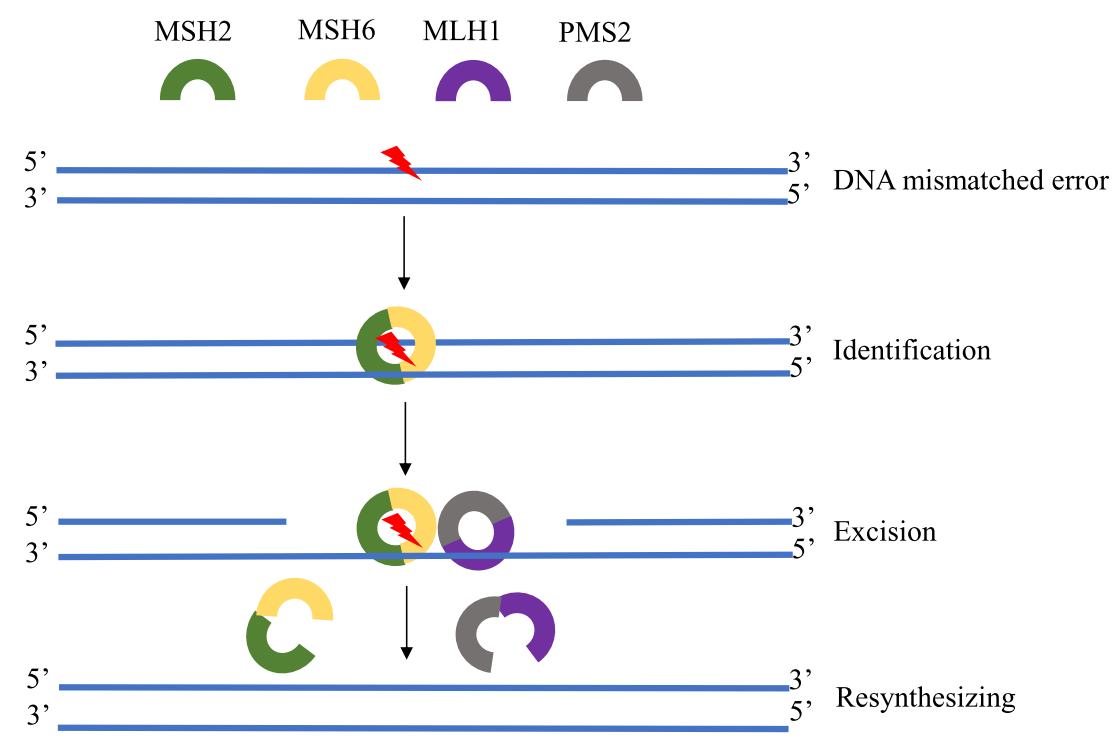

B

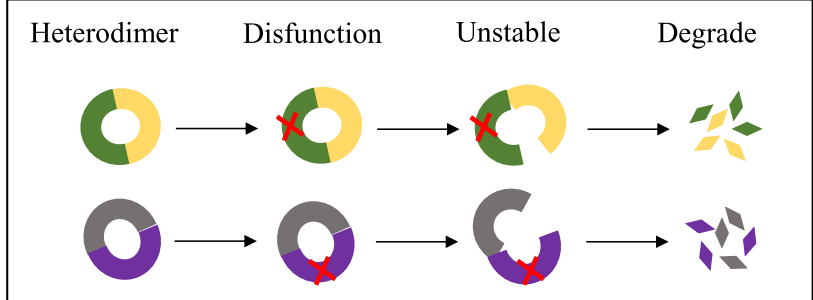

Fig. 1 The process of DNA mismatch repair 
multiple cancers, especially colon cancer and endometrial cancer. A lack of $M S H 2$, substantial mutations in the $M L H 1$ or $M S H 2$ genes, MLH1-methylation inactivation, and transcriptional silencing lead to Lynch syndrome [14, 15]. Deletion mutations in $M L H 1$ and $M S H 2$ account for $42-50 \%$ and 33-39\%; however, MSH6 and PMS2 mutations account for only $7-18 \%$ and less than $7 \%$, respectively [16-19]. A hypothesis that heterozygous germline deletions in the epithelial cell adhesion molecule $(E P C A M)$ gene as one factor that leads to $M S H 2$ defects has been confirmed, and the addition of EPCAM to the diagnostic panel for Lynch syndrome in $\mathrm{MSH}$ defective tumors has been advised $[19,20]$.

The inactivation of $M M R$ genes and MMR protein dysfunction may be the results of germline mutations or spontaneous hypermutation alterations, which may induce microsatellite instability (MSI). More than 100,000 areas of short tandem repetitive DNA sequences are the diagnostic sites of MSI. Two mononucleotide repeats (BAT25 and BAT26) and three dinucleotide repeats (D5S346, D2S123, and D17S250) are the standard sites in panels for MSI testing, as recommended by the National Cancer Institute in 1998 [21-23]. If two or more repeats are altered, the tumor is defined as MSI-H; if only one mutated sequence is found, the tumor is considered to be microsatellite instability-low (MSI-L). Otherwise, it is said to have microsatellite stability (MSS). There is a high level of consistency (almost 9095\%) between dMMR and MSI-H among many tumors; therefore, these two terms are used almost interchangeably [24]. MSI-H or dMMR has been widely detected and reported in Lynch syndrome-associated tumors, usually in colorectal cancer (CRC) [12], gastrointestinal adenocarcinoma [23], and endometrial cancer [25]. However, MSI-H or dMMR rarely appears in breast cancer [26], prostate cancer [27], and lung adenocarcinoma [9]. MSI-H varies from $0-31.37 \%$ in 39 cancer types. Endometrial carcinoma of the uterine corpus, colon adenocarcinoma, and stomach adenocarcinoma rank in the top 3 in terms of the prevalence of MSI-H, followed by rectal adenocarcinoma, adrenocortical carcinoma, and uterine carcinosarcoma. MSI-H has not been detected in more than ten tumors, as shown in Table 1 [28-30]. The prevalence of MSI-H in these studies was mostly derived from tissues of early-stage tumors [2830]. Le DT et al. reported that dMMR occurred more often in early-stage tumors than in late-stage tumors (stage IV) [30]. Venderbosch [31] also found that the incidence of dMMR in metastatic CRC was $5 \%$, which was lower than that (19.72\%) in early-stage CRC. MOSAIC, MANTIS, and next-generation sequencing were used to analyze MSI status [27-29], as sensitive standardized detection of MSI is necessary.

\section{The relationship between MMR and multiple tumors}

In this review, $M M R$ gene expression of 12,821 samples from 33 different tumors were pooled and analyzed through The Cancer Genome Atlas (TCGA) database (http://www.cbioportal.org/). Data from all TCGA cohorts were combined to produce this PanCancer dataset. Values of gene expression from the RNAseq experiment shown in Fig. 2 are $\log _{2}(x+1)$ transformed RSEM values. The expression of $M M R$ genes is different in many tumors and even in the same tumor. Generally, the expression of MSH6 is almost always the highest,

Table 1 Prevalence of MSI-H in 39 cancer types

\begin{tabular}{llllllll}
\hline Cancer type & MSI-H (\%) & Cancer type & MSI-H (\%) & Cancer type & MSI-H (\%) & Cancer type & MSI-H (\%) \\
\hline UCEC & $17.00-31.37$ & BRCA & $0.00-1.53$ & PRAD & $0.60-3.00$ & KICH & 0.00 \\
COAD & $6.00-19.72$ & KIRC & 1.47 & LUAD & $0.53-1.00$ & KIRP & Lo \\
STAD & $9.00-19.09$ & OV & $1.37-2.00$ & BLCA & 0.49 & LAML & NPC \\
READ & 5.73 & CHOL & $1.35-3.00$ & NBL & 0.45 & 0.00 \\
ACC & 4.35 & THYM & 0.81 & LGG & 0.39 & PAAD & $0-2.00$ \\
UCS & $3.00-3.51$ & LIHC & $0.80-3.00$ & CLL & 0.30 & PCPG & 0.00 \\
CESC & $2.62-4.00$ & HNSC & 0.78 & GBM & 0.25 & TGCT & 0.00 \\
WT & 2.44 & SARC & 0.78 & AML & 0.00 & THCA & $0.00-3.00$ \\
MESO & 2.41 & SKCM & $0.00-0.64$ & CTCL & 0.00 & UVM & $0.00-2.00$ \\
ESCA & 1.63 & LUSC & 0.60 & DLBC & 0.00 &
\end{tabular}

Abbreviations: UCEC uterine corpus endometrial carcinoma, COAD colon adenocarcinoma, STAD stomach adenocarcinoma, READ rectal adenocarcinoma, $A C C$ adrenocortical carcinoma, UCS uterine carcinosarcoma, CESC cervical squamous cell carcinoma and endocervical adenocarcinoma, WT Wilms tumor, MESO mesothelioma, ESCA esophageal carcinoma, BRCA breast carcinoma, KIRC kidney renal clear cell carcinoma, OV ovarian serous cystadenocarcinoma, CHOL cholangiocarcinoma, THYM thymoma, LIHC liver hepatocellular carcinoma, HNSC head and neck squamous cell carcinoma, SARC sarcoma, SKCM skin cutaneous melanoma, LUSC lung squamous cell carcinoma, PRAD prostate adenocarcinoma, LUAD lung adenocarcinoma, BLCA bladder carcinoma, NBL pediatric neuroblastoma, $L G G$ lower-grade glioma, CLL chronic lymphocytic leukemia, GBM glioblastoma multiforme, $A M L$ pediatric acute myeloid leukemia, $C T C L$ cutaneous T cell lymphoma, DLBC diffuse large B cell lymphoma, KICH kidney chromophobe, KIRP kidney renal papillary cell carcinoma, $L A M L$ acute myeloid leukemia, NPC nasopharyngeal carcinoma, PAAD pancreatic adenocarcinoma, PCPG pheochromocytoma and paraganglioma, TGCT testicular germ cell tumor, THCA thyroid carcinoma, UVM uveal melanoma 


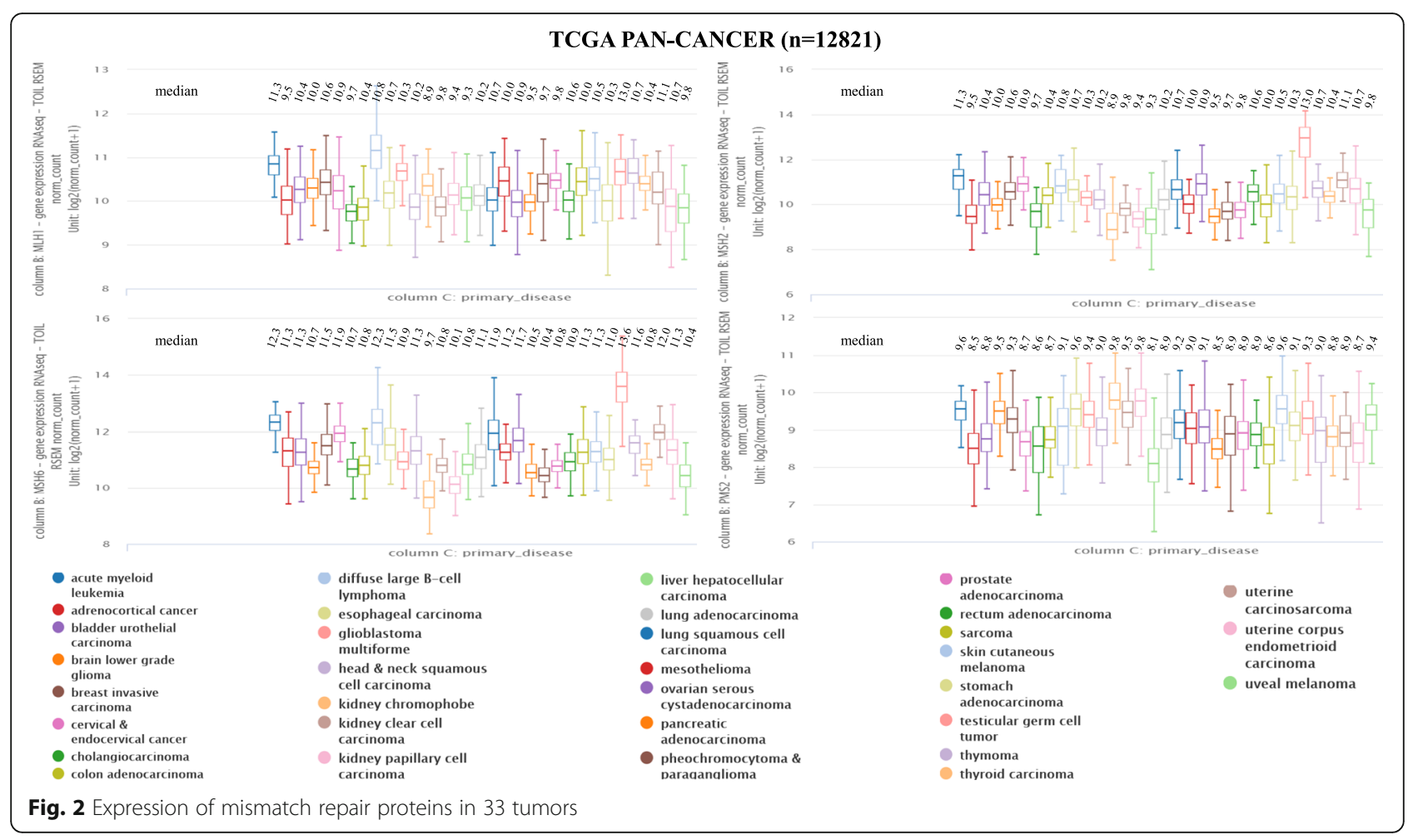

while PMS2 expression is the lowest. MLH1 gene expression is observed more often in acute myeloid leukemia, glioblastoma multiforme, and testicular germ cell tumors. MSH6 and MSH2 are expressed more frequently in acute myeloid leukemia, testicular germ cell tumors and uterine carcinosarcoma. However, PMS2 gene expression in the kidney chromophobe and kidney papillary cell carcinoma is higher than in other tumors (see Fig. 2). The correlations among MLH1, PMS2, MSH2, and MSH6 were also demonstrated using the TCGA. Excellent positive correlations were observed among the four $M M R$ genes (all $r>0.97$ ) (see Fig. 3). The good correlations coincide with the heterodimeric characteristic of these four genes.

The survival analysis based on the TCGA suggests a significant association between the expression of $M M R$ genes and prognosis in several tumors. In general, dMMR is correlated with an improved median overall survival (mOS) in most tumors other than head and neck cancer and pancreatic cancer. MLH1- is a prognostic factor in esophageal carcinoma and liver hepatocellular carcinoma $(P=0.049,0.039$, respectively), and MSH2- is correlated with improved mOS of bladder urothelial carcinoma, liver hepatocellular carcinoma, prostate adenocarcinoma, and sarcoma $(P=0.029$, $0.002,0.011$, and 0.001 , respectively). The mOS of the MSH6- group is prolonged compared with that of the $M S H 6+$ group in patients with bladder urothelial carcinoma $(P=0.015)$. Except for pancreatic cancer, $P M S 2-$ patients exhibit no survival benefit in most cancers (see Additional file 1: Figure S1). A comprehensive analysis indicated that mOS was improved only in esophageal carcinoma and liver hepatocellular carcinoma patients with four MMR gene deficiencies $(P=0.049$ and 0.001 , respectively) (see Additional file 2: Figure S2).

\section{The predictive value of $\mathrm{dMMR} / \mathrm{MSI}-\mathrm{H}$ in multiple tumors}

A strong clinical relationship is observed between MMR status and CRC. dMMR/MSI-H occurs in up to $15 \%$ of sporadic colon cancers [32]. Several clinicopathological variables, such as proximal tumor location, advanced age (> 65 years), poor differentiation, diploid DNA content, and the BRAF V600E mutation were found to be associated with the prevalence of MSI-H [32]. MLH1 dysfunction is responsible for most tumors in sporadic CRC patients with $\mathrm{dMMR}$ because its transcriptional promoter gene is silenced due to CpG island hypermethylation. The prognostic and predictive values of MMR in CRC are different in early-stage and late-stage. Most results indicated that dMMR is a positive prognostic factor in early-stage (II/III) rather than late-stage (IV) [30, 31, 33-36]. Ribic et al. [33] observed that patients with MSI-H had significant increased a 5-year survival rate compared with the MSI-L or MSS counterparts with stage II or stage III CRC who did not receive fluorouracil-based adjuvant chemotherapy (88.0\% versus $66.4 \%, P=0.004$ ), but the 5 -year survival rate of the former group was not significantly increased in 


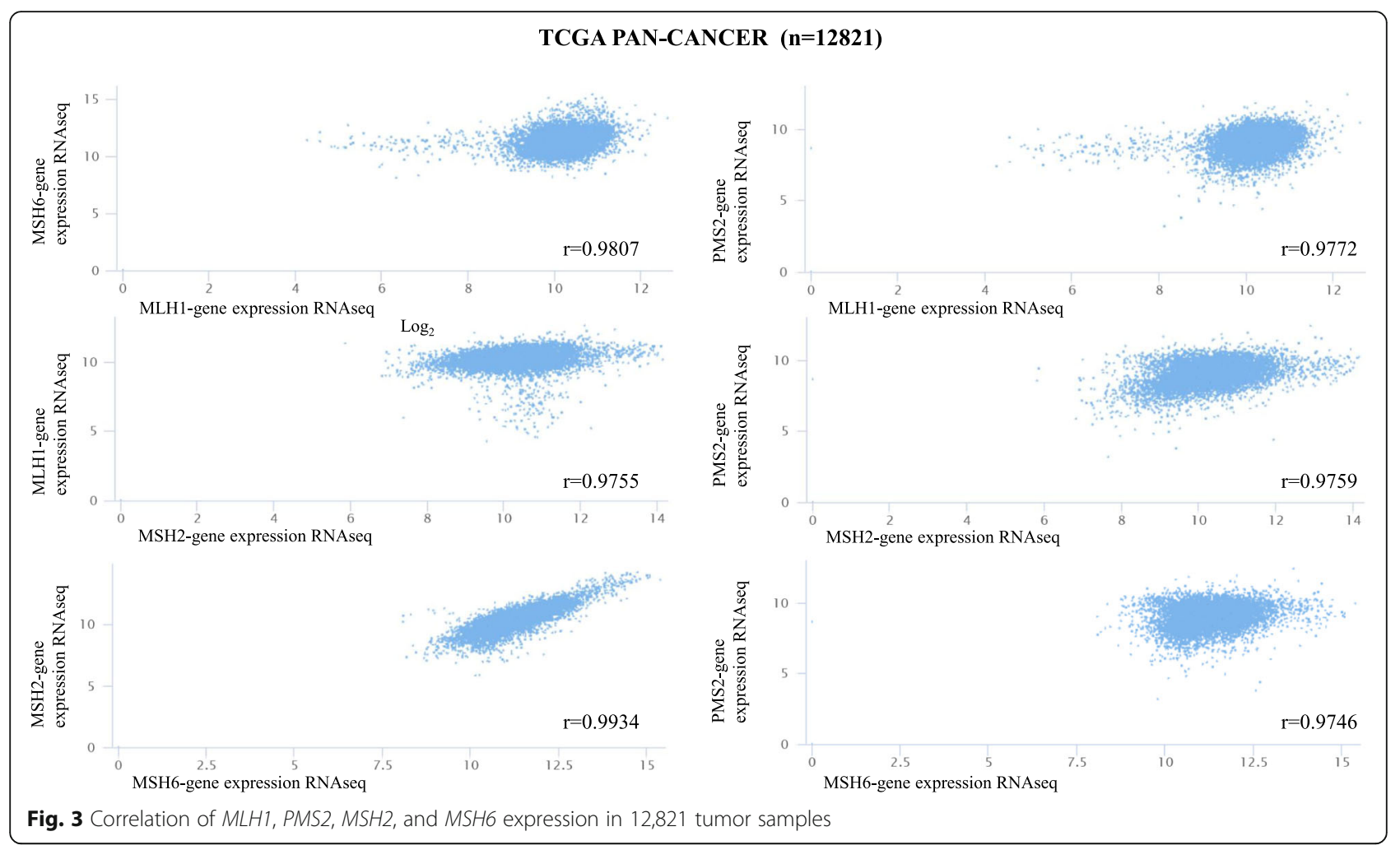

patients who received adjuvant chemotherapy (70.7\% versus $75.5 \%, P=0.66$ ). Guastadisegni [34] demonstrated that the odds ratio (OR) for OS associated with MSI-H was 0.6 $(P<0.0001)$ in patients with stages I-IV and $0.65(P<$ $0.0001)$ in patients with stages II-III CRC and that the OR for disease-free survival (DFS) was $0.58(P<0.0001)$. They pooled the data and showed that MSS patients treated with 5-fluorouracil had a better prognosis but that the benefit was not obvious for MSI-H CRC patients (OR 0.52 , 95\% CI $0.4-0.6, P<0.0001$ versus OR $0.69,95 \%$ CI $0.3-1.5, P=0.10)$. Sargent et al. [35] also concluded that patients with stages II-III CRC with pMMR exhibited improved DFS (hazard ratio [HR] 0.67, 95\% CI 0.48-0.93, $P$ $=0.02$ ) resulting from adjuvant therapy compared with those who underwent surgery alone. Regarding the predictive value of MMR status to the response to adjuvant irinotecan- or oxaliplatin-based treatment in stage III CRC patients is contradictory [37-40]. MSI-H or dMMR has a good prognostic predictive value in early-stage CRC settings without adjuvant chemotherapy and plays a negative predictive role for adjuvant fluorouracil-based chemotherapy in patients with resected CRC. However, the value of dMMR/MSI-H in metastatic CRC (mCRC) is opposite to that of early-stage CRC. A meta-analysis confirmed that mCRC patients with dMMR had poorer survival compared with pMMR patients, which might be due to a BRAF V600E mutation. The median progressive-free survival (mPFS) was 6.2 months in dMMR patients and 7.6 months in pMMR patients (HR 1.33, $P=0.001$ ), while the mOS was 13.6 months and 16.8 months, respectively (HR 1.35, $P=0.001$ ) [31]. The study of Mayo Clinic showed that $\mathrm{mCRC}$ patients with MSI-H had earlier disease recurrence (12.9 months vs. 20.9 months, $P=0.034)$ and poorer OS (28.1 months vs. 37.4 months, $P=0.99$ ) than MSS patients [36]. Detection of a BRAF V600E mutation is recommended in sporadic MSI tumors with silenced MLH1, as the presence of a BRAF V600E mutation strongly suggests that the etiology of the disease is sporadic [41].

The predictive value of dMMR was also investigated in other tumors. dMMR has been demonstrated in $20-40 \%$ of endometrial cancers [25, 42], but data on its prognostic value are controversial [25, 43, 44]. A meta-analysis including 23 studies found no association between OS (HR 2.0, $P=0.11$ ) or DFS (HR 1.31, $P=0.66$ ) and dMMR [45] in endometrial cancer. MSI frequency or dMMR expression in ovarian tumors varied from $5-13 \%$ [46-48] in MSI patients and from $2-29 \%$ in dMMR patients [49]. dMMR as a positive predictive biomarker for survival or response in ovarian cancers has not been confirmed [50, 51]. In gastric cancer (GC), MSI-H has been identified in approximately $10-20 \%$ of tumors, and patients with MSI-H demonstrate an improved survival compared with patients with MSS [52, 53]. However, data on the predictive value of MSI for GC patients treated with fluorouracil-based chemotherapy are conflicting $[54,55]$. In a study on melanoma, the expression 
of MSI was increased when the disease progressed from benign to malignant and then to metastatic [56]. Related studies in other tumors are few in number and limited, and therefore, evidence of the prognostic value is insufficient.

\section{dMMR/MSI-H predicts the efficacy of anti-PD-1/ PD-L1 immunotherapy}

Anti-PD-1/PD-L1 immunotherapies have led to tremendous success in treating certain cancers, such as melanoma, non-small cell lung cancer (NSCLC), mCRC, renal cell carcinoma, bladder cancer, head and neck squamous cell carcinoma, classical Hodgkin's lymphoma, and Merkel cell carcinoma [1-6, 57-63]. However, only a small fraction of patients with these malignancies are sensitive to ICB therapies. For patients with NSCLC or metastatic melanoma $[1,2,60]$, only $15.2-20 \%$ of patients who received single ICB therapy achieved objective response and $33.2-49 \%$ of patients obtained disease control. The precise recognition of targeted patients has always been the common goal of the researchers. Recent works suggest that MMR status could serve as a candidate biomarker and predict the responses of patients with solid tumors to ICB, irrespective of cancer type. Impressive results of pembrolizumab in patients with $\mathrm{dMMR}$ or MSI-H tumors after progression from prior chemotherapies have been shown in the KEYNOTE-016, 164, 012, 028, and 158 trials [8]. 149 patients with 15 different MSI-H or dMMR tumors were enrolled in the five trials. Patients with MSI-H/dMMR non-CRC were prospectively enrolled in single-arm trials (KEYNOTE-016, 158) or retrospectively identified in multi-cohort trials (KEYNOTE-012, 028) or in patients with one of 10 rare tumor types (KEYNOTE-158). 28 patients with CRC and 30 patients with non-CRC were included in KEYNOTE016 trial, and 61 patients with CRC were enrolled in the initial interim analysis of KEYNOTE-164 trials. There were 6, 5, and 19 patients enrolled in KEYNOTE-012, 028, and 158 trials, respectively. Patients received pembrolizumab at $200 \mathrm{mg}$ intravenously every 3 weeks in KEYNOTE-164, 158, and at $10 \mathrm{mg} / \mathrm{kg}$ intravenously every 2 weeks in KEYNOTE-028, 016, and 012 for 2 years until rapid disease progression or severe toxicity. The summarized results showed the overall response rate (ORR) was $39.6 \%$ (95\% CI 31.7-47.9); moreover, the duration of response ranged from 1.6 to 27 months, with $78 \%$ of responses sustaining longer than 6 months $[8,64]$. Pembrolizumab led to a durable response and survival benefits in patients with $\mathrm{dMMR}$ chemotherapy-refractory progressive metastatic tumors. Based on the above results, in 2017, the FDA accelerated the approval of pembrolizumab as a second- or higher-line choice for the treatment of patients with unresectable or metastatic dMMR/MSI-H solid tumors, irrespective of tumor type or site. This approval for a drug indication is noteworthy because it is the first time that one biomarker defined an indication regardless of the primary tumor site. However, further clinical trials consisting of sufficient number of patients and adequate followup are necessary to verify the efficacy of pembrolizumab in patients with $\mathrm{dMMR} / \mathrm{MSI}-\mathrm{H}$.

As the partial published results of the KEYNOTE-016 trial, 41 patients were enrolled and assigned to the CRC with dMMR (11 patients), CRC with pMMR (21 patients), and non-CRC with dMMR (9 patients) groups. The outcome showed that the immune-related ORR and PFS rates were $40 \%$ and $78 \%$ in dMMR CRC patients, $71 \%$ and $67 \%$ in dMMR non-CRC patients, and $0 \%$ and $11 \%$ in pMMR cancers. Both the MPFS and mOS were not reached in dMMR CRC patients in contrast to the 2.2 and 5.0 months observed in pMMR CRC patients [65]. The KEYNOTE-164 and 158 trials both reported the positive evidence to support the FDA approval of pembrolizumab. The relative update data are showed in the following description. Sixty-three patients with unresectable locally advanced or metastatic dMMR/MSI-H CRC after the failure of prior fluoropyrimidine-, oxaliplatin-, and irinotecan-based chemotherapy were enrolled in the KEYNOTE-164 trial, and 77 patients with any advanced MSI-H solid tumors after one or more prior regimen, except CRC, were enrolled in the KEYNOTE-158 trial. Both trials indicated similar objective response rates (ORRs) (32\% and 37.7\%), mPFS (4.1 months and 4.3 months), and 6-month OS rates $(87 \%$ and $73 \%)[66,67]$. In the KEYNOTE-164 trial, the 12 -month PFS rate was $41 \%$ and the 12 -month OS rate was $76 \%$.

The efficacy of nivolumab was also investigated in patients with $\mathrm{dMMR} / \mathrm{MSI}-\mathrm{H}$ tumors. The open-label, multicenter, phase II study CheckMate 142 evaluated the efficacy of nivolumab in $74 \mathrm{mCRC}$ patients with dMMR/ MSI-H tumors that progressed during or after one-line conventional chemotherapy. Patients received $3 \mathrm{mg} / \mathrm{kg}$ nivolumab intravenously every 2 weeks until progressive disease, unacceptable toxicity, or others. In all, $31.1 \%$ of patients achieved an objective response, $69 \%$ of patients had disease control for more than 12 weeks, and the PFS and OS rates at 12 months were 50\% and $73 \%$, respectively. The medium duration of responses was not reached until a median follow-up of 12 months [68]. Based on this meaningful and durable clinical benefit, nivolumab was approved by the FDA as a new treatment option for mCRC patients with MSI-H or dMMR who had disease progression after chemotherapy with fluoropyrimidine, oxaliplatin, and irinotecan.

dMMR/MSI-H also predict the efficacy of ICB combined therapy. Studies have confirmed that the efficacy of nivolumab combined with ipilimumab is better than that of nivolumab alone in small cell lung cancer (SCLC) 
and melanoma $[69,70]$. In the nivolumab plus ipilimumab cohort of the CheckMate 142 trial, 119 mCRC patients with $\mathrm{dMMR} / \mathrm{MSI}-\mathrm{H}$ who progressed after two or more prior therapies were enrolled. The results showed that the ORR was $55 \%$ and that the DCR for more than 12 weeks was $80 \%$; the 12 -month PFS rate was $71 \%$, and the corresponding OS rate was $85 \%$ regardless of PD-L1 expression, $B R A F / K R A S$ mutation status, or clinical history of Lynch syndrome (see Table 2) [71]. A preliminary result from $\mathrm{H}-\mathrm{JJ}$ Lenz et al. demonstrated that nivolumab plus low-dose ipilimumab had an inspiring and promising benefit as a first-line therapy for mCRC patients with $\mathrm{dMMR} / \mathrm{MSI}-\mathrm{H}$. The ORR and DCR were $60 \%(27 / 45)$ and $84 \%(38 / 45)$, respectively. The PFS rate was $78 \%$, and the OS rate was $83 \%$ at 12 months [72]. M Chalabi et al. conducted an exploratory phase II trial to investigate nivolumab plus ipilimumab as a neoadjuvant therapy in resectable, early-stage colon cancers with dMMR and pMMR. Seven dMMR and 8 pMMR patients were enrolled. A major pathological response was observed in $100 \%$ of the dMMR patients, but no response was observed in pMMR patients [73]. However, these trials were somewhat limited by the lack of random grouping and small sample size, and thus, further investigation is urgent and necessary (see Table 3).

Why does dMMR reflect the efficacy of immunotherapy? Le DT et al. reported that an average of 1782 somatic mutations per tumor and 578 potential neoantigens were found in dMMR tumors, compared with 73 mutations and 21 neoantigens in pMMR tumors by exome sequencing $(P=0.007)$. Higher numbers of somatic mutations and neoantigens were correlated with better responses and longer PFS. Furthermore, dMMR tumors have a dense infiltration of $\mathrm{CD} 8^{+}$TILs, which induce a better and more durable response [65]. In view of the abovementioned results, routine testing of the MMR status should be considered in the clinic regardless of tumor origin, which might bring an unexpected benefit to the patients with dMMR/MSI-H tumors. In summary, dMMR/MSI-H tumors treated with ICB demonstrate a durable response and a sustained survival benefit, and the combination of ICB therapies could further improve

Table 2 The relationship between ICB and dMMR/MSI-H

\begin{tabular}{|c|c|c|c|c|c|c|}
\hline Author/year & Cancer type & $N$ & Protocol & Results & PFS & OS \\
\hline \multirow[t]{4}{*}{$\begin{array}{l}\text { Le DT [65] } \\
2015\end{array}$} & dMMR CRC & 41 & $\begin{array}{l}\text { Pembrolizumab } 10 \text { mg/kg, } \\
\text { q14d, } 20 \text { weeks }\end{array}$ & ORR $40 \%$ & $\begin{array}{l}\text { 20-week PFS, 78\%; } \\
\text { mPFS: NR }\end{array}$ & mOS: NR \\
\hline & pMMR CRC & & & ORR 0\% & $\begin{array}{l}\text { 20-week PFS, } 11 \% \text {; } \\
\text { mPFS: } 2.2 \text { months }\end{array}$ & mOS, 5.0 months \\
\hline & $\begin{array}{l}\text { dMMR } \\
\text { non-CRC }\end{array}$ & & & ORR $71 \%$ & $\begin{array}{l}\text { 20-week PFS, 67\%; } \\
\text { mPFS: } 5.4 \text { months }\end{array}$ & mOS: NR \\
\hline & PMMR CRC & 25 & & $\begin{array}{l}\text { ORR 0\% } \\
\text { DCR16\% }\end{array}$ & mPFS, 2.4 months & mOS, 6 months \\
\hline $\begin{array}{l}\text { Le DT [30] } \\
2017\end{array}$ & $\begin{array}{l}12 \text { tumors } \\
\text { with dMMR }\end{array}$ & 86 & $\begin{array}{l}\text { Pembrolizumab } 10 \text { mg/kg, } \\
\text { q14d, } 2 \text { years }\end{array}$ & $\begin{array}{l}\text { ORR 53\% } \\
\text { DCR 66\% }\end{array}$ & $\begin{array}{l}\text { 12-month PFS, 64\% } \\
\text { 24-month PFS, 53\%; } \\
\text { mPFS: NR }\end{array}$ & $\begin{array}{l}\text { 12-month OS, 76\% } \\
\text { 24-month OS, 64\%; } \\
\text { mOS: NR }\end{array}$ \\
\hline $\begin{array}{l}\text { Diaz LA [66] } \\
2017\end{array}$ & $\begin{array}{l}\text { Multiple types } \\
\text { of solid tumors }\end{array}$ & 77 & Pembrolizumab 200 mg, q3w, 35 cycles & $\begin{array}{l}\text { ORR 38\% } \\
\text { DCR 58\% }\end{array}$ & $\begin{array}{l}\text { 6-month PFS, 45\% } \\
\text { mPFS, } 4.3 \text { months }\end{array}$ & $\begin{array}{l}\text { 6-month OS, 73\%; } \\
\text { mOS: NR }\end{array}$ \\
\hline $\begin{array}{l}\text { D Le [67] } \\
2018\end{array}$ & $\begin{array}{l}\text { MMR/ } \\
\text { dMMR CRC }\end{array}$ & 63 & $\begin{array}{l}\text { Pembrolizumab } 200 \text { mg, } \\
\text { q3w, } 35 \text { cycles }\end{array}$ & $\begin{array}{l}\text { ORR 28\% } \\
\text { DCR } 51 \%\end{array}$ & $\begin{array}{l}\text { 6-month PFS, 43\% } \\
\text { 12-month PFS, 41\%; } \\
\text { mPFS, } 4.1 \text { months }\end{array}$ & $\begin{array}{l}\text { 6-month OS, 87\% } \\
\text { 12-month OS, 76\%; } \\
\text { mOS: NR }\end{array}$ \\
\hline $\begin{array}{l}\text { Overman MJ [68] } \\
2017\end{array}$ & $\begin{array}{l}\text { dMMR/ } \\
\text { MSI-H mCRC }\end{array}$ & 74 & $\begin{array}{l}\text { Nivolumab } 3 \text { mg/kg, q2w, } \\
\text { until PD }\end{array}$ & $\begin{array}{l}\text { ORR } 31 \% \\
\text { DCR } 69 \% \\
\text { ( } \geq 12 \text { weeks) }\end{array}$ & $\begin{array}{l}\text { 12-month PFS, } 50 \% \\
\text { mPFS, } 14.3 \text { months }\end{array}$ & $\begin{array}{l}\text { 12-month OS, 73\%; } \\
\text { mOS: NR }\end{array}$ \\
\hline $\begin{array}{l}\text { Overman MJ [71] } \\
2018\end{array}$ & $\begin{array}{l}\text { dMMR/ } \\
\text { MSI-H mCRC }\end{array}$ & 119 & $\begin{array}{l}\text { Nivolumab } 3 \text { mg/kg + ipilimumab } \\
1 \mathrm{mg} / \mathrm{kg}, \mathrm{q} 3 \mathrm{w}, 4 \text { doses, followed } \\
\text { by nivolumab } 3 \mathrm{mg} / \mathrm{kg} \text {, q2w, until PD }\end{array}$ & $\begin{array}{l}\text { ORR } 55 \% \\
\text { DCR } 80 \%\end{array}$ & $\begin{array}{l}\text { 9-month PFS, 76\% } \\
\text { 12-month PFS, 71\%; } \\
\text { mPFS: NR }\end{array}$ & $\begin{array}{l}\text { 9-month OS, 87\% } \\
\text { 12-month OS, 85\%; } \\
\text { mOS: NR }\end{array}$ \\
\hline $\begin{array}{l}\text { H-J J Lenz [72] } \\
2018\end{array}$ & $\begin{array}{l}\text { dMMR/ } \\
\text { MSI-H mCRC }\end{array}$ & 45 & $\begin{array}{l}\text { Nivolumab } 3 \mathrm{mg} / \mathrm{kg}, \mathrm{q} 2 \mathrm{w}+ \\
\text { ipilimumab } 1 \mathrm{mg} / \mathrm{kg} \text {, q6w, until } \\
\text { PD (as first-line treatment) }\end{array}$ & $\begin{array}{l}\text { ORR } 60 \% \\
\text { DCR } 84 \%\end{array}$ & $\begin{array}{l}\text { 12-month PFS, 78\%; } \\
\text { mPFS: NR }\end{array}$ & $\begin{array}{l}\text { 12-month OS: 83\%; } \\
\text { mOS: NR }\end{array}$ \\
\hline $\begin{array}{l}\text { M Chalabi [73] } \\
2018\end{array}$ & $\begin{array}{l}\text { dMMR early- } \\
\text { stage CC } \\
\text { pMMR early- } \\
\text { stage CC }\end{array}$ & $\begin{array}{l}7 \\
8\end{array}$ & $\begin{array}{l}\text { Nivolumab } 3 \mathrm{mg} / \mathrm{kg}, \mathrm{d} 1, \mathrm{~d} 15+ \\
\text { ipilimumab } 1 \mathrm{mg} / \mathrm{kg} \text {, d1 }\end{array}$ & $\begin{array}{l}\text { mPR 100\% } \\
\text { mPR 0\% }\end{array}$ & NA & NA \\
\hline
\end{tabular}

Abbreviations: $d M M R$ mismatch repair deficient, $C R C$ colorectal cancer, $m C R C$ metastatic colorectal cancer, $C C$ colon cancers, $p M M R$ mismatch repair proficient, $O R R$ objective response rate, PFS progression-free survival, $m P F S$ median progression-free survival, NR not reached (the responses were durable and the results were not reached until the end of follow-up), $m O S$ median overall survival, $D C R$ disease control rate, OS overall survival, $m C R C$ metastatic colorectal cancer, $M S I-H$ microsatellite instability-high, $P D$ disease progression, $M P R$ major pathological response, NA not available 
Table 3 Ongoing clinical trials evaluating ICB therapies in dMMR/MSI-H tumors

\begin{tabular}{|c|c|c|c|c|c|}
\hline Clinical trial & Phase & Drug treatment & Drugs & Tumor type & $\begin{array}{l}\text { Current } \\
\text { status }\end{array}$ \\
\hline NCT03150706 & $\|$ & Avelumab & Anti-PD-L1 mAb & $\begin{array}{l}\text { Previously treated dMMR/MSI-H } \\
\text { or POLE-mutated mCRC }\end{array}$ & Ongoing \\
\hline NCT03435107 & $\|$ & Durvalumab & Anti-PD-L1 mAb & $\begin{array}{l}\text { Previously treated dMMR/MSI-H } \\
\text { or POLE-mutated mCRC }\end{array}$ & Ongoing \\
\hline NCT02983578 & $\|$ & Durvalumab (MEDI4736) + AZD9150 & $\begin{array}{l}\text { Anti-PD-L1 mAb + } \\
\text { Antisense STAT3 }\end{array}$ & $\begin{array}{l}\text { dMMR CRC, NSCLC, and } \\
\text { advanced pancreatic cancer }\end{array}$ & Ongoing \\
\hline NCT02997228 & III & $\begin{array}{l}\text { Atezolizumab + mFOLFOX } 6+\text { bevacizumab } \\
\text { versus mFOLFOX } 6+\text { bevacizumab versus } \\
\text { atezolizumab }\end{array}$ & Anti-PD-L1 mAb & dMMR mCRC & Ongoing \\
\hline NCT02912559 & III & $\begin{array}{l}\text { Atezolizumab }+ \text { standard chemotherapy* } \\
\text { versus standard chemotherapy* }\end{array}$ & Anti-PD-L1 mAb & dMMR stage III resected CRC & Ongoing \\
\hline NCT03257163 & $\|$ & $\begin{array}{l}\text { Pembrolizumab }+ \text { capecitabine }+ \\
\text { radiation therapy }\end{array}$ & Anti-PD-1 mAb & $\begin{array}{l}\mathrm{dMMR} \text { and Epstein-Barr virus } \\
\text { positive GC }\end{array}$ & Ongoing \\
\hline NCT02563002 & III & Pembrolizumab versus standard therapy** & Anti-PD-1 mAb & dMMR/MSI-H stage IV CRC & $\begin{array}{l}\text { Not } \\
\text { recruiting }\end{array}$ \\
\hline NCT03236935 & $\mathrm{lb}$ & Pembrolizumab + L-NMMA & $\begin{array}{l}\text { Anti-PD-1 } \mathrm{mAb}+ \\
\text { nitric oxide synthase inhibitor }\end{array}$ & $\begin{array}{l}\text { dMMR/MSI-H cancer, melanoma, } \\
\text { NSCLC, HNSCC, classic HL, and } \\
\text { urothelial carcinoma }\end{array}$ & Ongoing \\
\hline NCT03607890 & $\|$ & Nivolumab + relatlimab & $\begin{array}{l}\text { Anti-PD-1 mAb + anti- } \\
\text { LAG-3 mAb }\end{array}$ & $\begin{array}{l}\text { MSI-H solid tumors refractory } \\
\text { to prior PD-(L)1 therapy }\end{array}$ & $\begin{array}{l}\text { Not } \\
\text { recruiting }\end{array}$ \\
\hline NCT02992964 & $|/| \mid$ & Nivolumab & Anti-PD-1 mAb & $\begin{array}{l}\text { Pediatric patients with } \\
\text { hypermutant cancers, } \\
\text { including biallelic MMR } \\
\text { syndrome }\end{array}$ & Ongoing \\
\hline NCT03241745 & $\|$ & Nivolumab & Anti-PD-1 mAb & $\begin{array}{l}\text { dMMR/MSI-H/hypermutated } \\
\text { uterine cancer }\end{array}$ & Ongoing \\
\hline NCT02060188 & $\|$ & $\begin{array}{l}\text { Nivolumab versus nivolumab + ipilimumab } \\
\text { or nivolumab + ipilimumab + cobimetinib } \\
\text { or nivolumab + BMS-986016 or nivolumab } \\
+ \text { daratumumab }\end{array}$ & $\begin{array}{l}\text { Anti-PD-1 mAb + Anti- } \\
\text { CTLA-4 mAb + MEK inhibitor + } \\
\text { anti-LAG-3 mAb + anti-CD38 mAb }\end{array}$ & $\begin{array}{l}\text { dMMR/pMMR/MSI-H/ } \\
\text { MSI-L/MSS CRC }\end{array}$ & Ongoing \\
\hline
\end{tabular}

Abbreviations: ICBs immune checkpoint blockades, PD-L1 programmed death-ligand 1, $m A b$ monoclonal antibody, $d M M R$ mismatch repair deficient, $p M M R$ mismatch repair proficient, MSI-H microsatellite instability-high, MSI-L microsatellite instability-low, MSS microsatellite stable, CTLA-4 cytotoxic T-lymphocyte protein 4, $m C R C$ metastatic colorectal cancer, CRC colorectal cancer, NSCLC non-small cell lung cancer, GC gastric cancer, HNSCC head and neck squamous cell carcinoma, HL Hodgkin lymphoma, mFOLFOX 6 denotes fluorouracil plus leucovorin calcium and oxaliplatin *Standard chemotherapy denotes fluorouracil plus leucovorin calcium and oxaliplatin **Standard therapy denotes mFOLFOX6 or mFOLFOX6 plus bevacizumab, or mFOLFOX6 plus cetuximab, or FOLFIRI, or FOLFIRI plus bevacizumab, or FOLFIRI plus cetuximab (FOLFIRI denotes irinotecan plus leucovorin and fluorouracil)

outcomes in these patients. The survival benefit remains to be explored in patients with refractory metastatic cancers. Table 3 shows the ongoing clinical trials evaluating ICB therapies in dMMR/MSI-H tumors. dMMR tumors are more frequent in early-stage cancers than in metastatic cancers, and therefore, the efficacy of immunotherapy in early-stage tumors is worthy of further investigation.

\section{Relationship between dMMR/MSI-H and other immune biomarkers}

PD-1/PD-L1 checkpoints have important functions in maintaining immune-tolerance and preventing effective antitumor immunity. The numbers of PD- $1^{+}$TILs are significantly different among various cancer types and range from $0 \%$ in extraskeletal myxoid chondrosarcomas and uterine sarcoma to $93 \%$ in ovarian cancer [49, 74].
The positive rates of membranous $\mathrm{PD}-\mathrm{L} 1$ expression vary from $50-97 \%$ in NSCLC, bladder carcinoma, renal cell carcinoma, endometrial cancer, melanoma, and sarcomas, but its expression is less than $10 \%$ in liver cancer and is absent in Merkel cell carcinoma [74]. PD-L1 ${ }^{+}$expression has been used as common stratification factor in many clinical trials and used as an important biomarker to guide the ICB therapy in clinical practice [61, 75-80]. PD- $\mathrm{L}^{+}$expression is closely related to dMMR/ MSI-H status. Both Gatalica and Inaguma reported that the proportion of PD-L1 ${ }^{+}$expression in dMMR/MSI-H CRC was significantly higher than in pMMR/MSS CRC $[74,81]$. Kim ST et al. reported that PD- $\mathrm{L}^{+}$expression was $38.9 \%$ in MLH1/MSH2-negative solid tumors compared with $15.2 \%$ in pMMR tumors [82]. In other studies, the PD- $\mathrm{L}^{+}$rate varied from $12.1-35.2 \%$ in $\mathrm{pMMR}$ GC and from $46.7-60.0 \%$ in dMMR GC $(P<0.01)$ [83, 
84] (see Table 4). Lee SJ et al. [85] showed that the expression of PD-L1, lymphocyte-activation gene 3 (LAG3), and indolamine $2^{\prime} 3^{\prime}$-dioxygenase 1 (IDO1) in TILs was $68.6 \%, 13.5 \%$, and $28.1 \%$, respectively, in 89 patients with MSI-H colon cancer. A higher number of mutations in DNA coding sequences in MSI-H tumors have more potential to stimulate the host to generate neoantigens and trigger immune activation [65, 81]. Llosa NJ et al. indicated that the levels of PD-1, PD-L1, CTLA-4, LAG3, and IDO1 have been found to be significantly upregulated to balance the activated immune response in MSI-H tumors compared with MSS tumors [86]. Therefore, blocking the interaction between PD-1/PD-L1 and other immune negative regulatory pathways may increase activation of Th1 cytotoxic immune responses and significantly enhance the ability of the host to kill cancer cells, especially in dMMR/MSI-H tumors [87].

$\mathrm{TMB}$ is another promising predictor for anti-PD-1/PDL1 immunotherapy compared to dMMR/MSI-H, and the relevant content has been widely studied in lung cancer [88-92], melanoma [93], bladder cancer [94], and others. The exploratory subgroup analyses in the CheckMate 026 trial demonstrated that patients with previously untreated stage IV or recurrent NSCLC obtained significant ORR and $\mathrm{mPFS}$ benefits from nivolumab than platinum-based chemotherapy in the high TMB (TMB $\geq 243$ mutations) group (ORR $47 \%$ vs $28 \%$; mPFS 9.7 months vs 5.8 months) . No significant clinical benefit was observed in regards to ORR or PFS in the low $(0<\mathrm{TMB}<100$ mutations $)$ or medium TMB $(100 \leq \mathrm{TMB}<243$ mutations $)$ group [88]. In the CheckMate 568 trial, the ORR was $4 \%, 10 \%, 44 \%$, and $39 \%$ when the TMB cutoffs were $<5,<10, \geq 10$, and $\geq 15 \mathrm{mut} / \mathrm{Mb}$ in NSCLC patients treated with nivolumab plus ipilimumab as a first-line therapy. Subsequently, $\mathrm{TMB} \geq 10 \mathrm{mut} / \mathrm{Mb}$ was regarded as the criteria to differentiate the high TMB and low TMB cohorts in the CheckMate 227 trial [89]. The prospective phase III trial confirmed that nivolumab plus ipilimumab resulted in a significantly longer PFS and higher ORR only in high TMB patients with stage IV or recurrent NSCLC compared with chemotherapy (mPFS 7.2 months vs 5.5 months; ORR $45.3 \%$ vs $26.9 \%$ ) [90]. According to the abovementioned trials, the National Comprehensive Cancer Network guidelines firstly recommended that TMB was an emerging biomarker to identify patients with NSCLC for nivolumab or nivolumab plus ipilimumab in version 1 of 2019 [80]. The CheckMate 032 trial demonstrated better clinical benefit in high TMB (TMB $\geq 248$ mutations) patients with SCLC [91]. Robert M. Samstein et al. reported that higher TMB was significantly associated with better OS in 1662 patients treated with either anti-CTLA-4 or anti-PD-1 therapies in diverse cancer types. These studies provided robust evidence for the predictive power of TMB in guiding the application of ICB [95]. TMB is commonly detected through tissue, and blood detection is the substitute due to the lack of tissue. Gandara et al. showed that high blood-based TMB (bTMB $\geq 16$ mut/Mb) levels were positively associated with improved PFS and OS in NSCLC patients treated with atezolizumab versus docetaxel as a second-line or more-line choice [92]. More recently, Zhijie Wang et al. found that BTMB can be well estimated and measured by a cancer gene panel (CGP) named NCCGP150 in patients with NSCLC. In clinical validation, 50 patients with NSCLC with high bTMB $(\geq 6$ mut/Mb) was

Table 4 The relationship between PD-L1 and dMMR/PMMR

\begin{tabular}{|c|c|c|c|c|c|c|c|c|}
\hline Author/year & Tumor & $N$ & PD-L1+ (\%) & $\mathrm{dMMR}(\%)$ & $\begin{array}{l}\text { PD-L } 1^{+} \text {in } \\
\text { dMMR } \\
\text { tumors (\%) }\end{array}$ & $\begin{array}{l}\text { PD-L1+ in } \\
\text { pMMR } \\
\text { tumors (\%) }\end{array}$ & $P$ & $\begin{array}{l}\text { The impact of PD-L1 or } \\
\text { dMMR on survival }\end{array}$ \\
\hline $\begin{array}{l}\text { Gatalica Z [74] } \\
2014\end{array}$ & CC & 87 & 20.7 & 31.0 & 38.0 & 13.0 & 0.02 & NA \\
\hline $\begin{array}{l}\text { Inaguma S [83] } \\
2016\end{array}$ & CRC & 506 & NA & NA & 44.7 & 6.8 & $<0.01$ & NA \\
\hline $\begin{array}{l}\text { Inaguma S [83] } \\
2016\end{array}$ & $\mathrm{GC}$ & 180 & NA & NA & 46.7 & 12.1 & $<0.01$ & NA \\
\hline $\begin{array}{l}\text { Kim ST [82] } \\
2017\end{array}$ & $\begin{array}{l}\text { Advanced Gl, } \\
\text { GU, and others }\end{array}$ & 430 & $\begin{array}{l}16.5 \text { in all, } 28.6 \text { in } \\
\text { melanoma, } \\
22.4 \text { in GC, } 20.9 \text { in CRC, } \\
12.5 \text { in BTC, } 7.1 \text { in GU, } \\
6.7 \text { in HCC, } 0.0 \text { in } \\
\text { pancreatic cancer and } \\
\text { sarcoma }\end{array}$ & $\begin{array}{l}4.5 \text { in all } \\
7.1 \text { in GC } \\
6.7 \text { in } \mathrm{HCC} \\
4.4 \text { in CRC }\end{array}$ & 38.9 & 15.2 & $<0.01$ & $\begin{array}{l}P=0.535 \text { in } \mathrm{GC} \\
P=0.231 \text { in } \mathrm{mCRC} \\
P=0.508 \text { in sarcoma }\end{array}$ \\
\hline $\begin{array}{l}\text { Mills AM [26] } \\
2018\end{array}$ & $\begin{array}{l}\text { Breast } \\
\text { carcinoma }\end{array}$ & 245 & $\begin{array}{l}12.0 \text { in all } \\
32.0 \text { in TNDC }\end{array}$ & 0.04 & 100.0 & NA & NA & NA \\
\hline $\begin{array}{l}\text { Wang L [84] } \\
2018\end{array}$ & GC & 550 & 37.3 & 8.2 & 60.0 & 35.2 & $<0.01$ & NA \\
\hline
\end{tabular}

Abbreviations: $N$ number, $P D-L 1$ programmed death-ligand 1, $d M M R$ mismatch repair deficient, $p M M R$ mismatch repair proficient, $N A$ not available, $C C$ colon cancer, $C R C$ colorectal cancer, GC gastric cancer, Gl gastrointestinal cancer, GU genitourinary cancer, $B T C$ biliary tract cancer, $H C C$ hepatocellular carcinoma, $m C R C$ metastatic colorectal cancer, TNDC triple negative ductal carcinoma 
associated with prolonged mPFS and higher ORR than patients with low bTMB $(<6$ mut/Mb) (mPFS not reach vs $2.9 \mathrm{~m}$; ORR $39.3 \%$ vs $9.1 \%$ ) when treated with anti-PD-1/ PD-L1 therapies [96] (see Table 5).

Compared with dMMR/MSI-H or PD-1/PD-L1 expression, the TMB is emerging as a more accurate, comprehensive, and compelling potential biomarker that could predict the efficacy of ICB therapy. However, there is no consensus on the measuring of TMB status [95]. In several studies, most patients with MSI-H had high TMB levels; however, not all patients with high TMB levels had dMMR/MSI-H status or high PD-L1

Table 5 TMB predicts the efficacy of ICB therapy

\begin{tabular}{|c|c|c|c|c|c|c|c|c|}
\hline Clinical trial & Phase & Drug & TMB (mut/Mb) & Tumor & N & Response & PFS & OS \\
\hline \multirow[t]{4}{*}{ CheckMate026 [88] } & \multirow[t]{4}{*}{ III } & Nivolumab & \multirow[t]{2}{*}{$H \geq 243$} & \multirow[t]{4}{*}{ NSCLC } & 47 & ORR 47\% & *mPFS, 9.7 moths & $\begin{array}{l}\text { 1-year OS, 64\%; } \\
\text { mOS, } 18.3 \text { months }\end{array}$ \\
\hline & & $\begin{array}{l}\text { Platinum- } \\
\text { based CT }\end{array}$ & & & 60 & ORR 28\% & ${ }^{*} \mathrm{mPFS}, 5.8$ months & $\begin{array}{l}\text { 1-year OS, 60\%; } \\
\text { mOS, } 18.8 \text { months }\end{array}$ \\
\hline & & Nivolumab & \multirow[t]{2}{*}{$\begin{array}{l}\mathrm{L} 0 \text { to } 99 \text { and } M \\
100 \text { to } 242\end{array}$} & & 111 & ORR 23\% & mPFS, 4.1 months & $\begin{array}{l}\text { 1-year OS, 54\%; } \\
\text { mOS, } 12.7 \text { months }\end{array}$ \\
\hline & & $\begin{array}{l}\text { Platinum- } \\
\text { based } C T\end{array}$ & & & 94 & ORR 33\% & mPFS, 6.9 months & $\begin{array}{l}\text { 1-year OS, 53\%; } \\
\text { mOS, } 13.2 \text { months }\end{array}$ \\
\hline CheckMate568 [89] & $\|$ & $\begin{array}{l}\text { Nivolumab + } \\
\text { ipilimumab }\end{array}$ & $\begin{array}{l}<5 \\
5-10 \\
10-15 \\
\geq 15\end{array}$ & NSCLC & 288 & $\begin{array}{l}\text { ORR 4\%, ORR 10\%, } \\
\text { ORR 44\%, ORR 39\% }\end{array}$ & NA & NA \\
\hline \multirow[t]{4}{*}{ CheckMate227 [90] } & \multirow[t]{4}{*}{ III } & $\begin{array}{l}\text { Nivolumab + } \\
\text { ipilimumab }\end{array}$ & \multirow[t]{2}{*}{$\geq 10$} & \multirow[t]{4}{*}{ NSCLC } & 139 & $\begin{array}{l}\text { ORR 45.3\% } \\
\text { 1-year DoR 68\% }\end{array}$ & $\begin{array}{l}\text { *1-year PFS, 42.6\% } \\
\text { *mPFS, } 7.2 \text { months }\end{array}$ & NA \\
\hline & & $\begin{array}{l}\text { Platinum } \\
\text { doublet } C T\end{array}$ & & & \multirow[t]{3}{*}{160} & \multirow[t]{3}{*}{$\begin{array}{l}\text { ORR 26.9\% } \\
\text { 1-year DoR 25\% }\end{array}$} & $\begin{array}{l}{ }^{*} 1 \text {-year PFS, } 13.2 \% \\
{ }^{*} \text { mPFS, } 5.5 \text { months }\end{array}$ & \\
\hline & & $\begin{array}{l}\text { Nivolumab + } \\
\text { ipilimumab }\end{array}$ & $<10$ & & & & mPFS, 3.2 months & \\
\hline & & $\begin{array}{l}\text { Platinum } \\
\text { doublet } C T\end{array}$ & & & & & mPFS, 5.5 months & \\
\hline \multirow[t]{6}{*}{$\begin{array}{l}\text { CheckMate } 032 \\
\text { [91] }\end{array}$} & \multirow[t]{6}{*}{ Exploratory } & $\begin{array}{l}\text { Nivolumab + } \\
\text { ipilimumab }\end{array}$ & \multirow[t]{2}{*}{$H \geq 248$} & \multirow[t]{6}{*}{$\mathrm{SCLC}$} & 26 & ORR $46.2 \%$ & $\begin{array}{l}\text { 1-year PFS, 30.3\% } \\
\text { mPFS, 7.8 months }\end{array}$ & $\begin{array}{l}\text { 1-year OS, 62.4\%; } \\
\text { mOS, } 22.0 \text { months }\end{array}$ \\
\hline & & Nivolumab & & & 47 & ORR 21.3\% & $\begin{array}{l}\text { 1-year PFS, } 21.2 \% \\
\text { mPFS, } 1.4 \text { months }\end{array}$ & $\begin{array}{l}\text { 1-year OS, 35.2\%; } \\
\text { mOS, } 5.4 \text { months }\end{array}$ \\
\hline & & $\begin{array}{l}\text { Nivolumab + } \\
\text { ipilimumab }\end{array}$ & \multirow[t]{2}{*}{ M 143 to 247} & & 25 & ORR 16.0\% & $\begin{array}{l}\text { 1-year PFS, 8.0\% } \\
\text { mPFS, 1.3 months }\end{array}$ & $\begin{array}{l}\text { 1-year OS, } 19.6 \% \\
\text { mOS, } 3.6 \text { months }\end{array}$ \\
\hline & & Nivolumab & & & 44 & ORR 6.8\% & $\begin{array}{l}\text { 1-year PFS, 3.1\% } \\
\text { mPFS, } 1.3 \text { months }\end{array}$ & $\begin{array}{l}\text { 1-year OS, 26.0\%; } \\
\text { mOS, } 3.9 \text { months }\end{array}$ \\
\hline & & $\begin{array}{l}\text { Nivolumab + } \\
\text { ipilimumab }\end{array}$ & \multirow[t]{2}{*}{ L 0 to 143} & & 27 & ORR $22.2 \%$ & $\begin{array}{l}\text { 1-year PFS, 6.2\%; } \\
\text { mPFS, } 1.5 \text { months }\end{array}$ & $\begin{array}{l}\text { 1-year OS, 23.4\%; } \\
\text { mOS, } 3.4 \text { months }\end{array}$ \\
\hline & & Nivolumab & & & 42 & ORR 4.8\% & $\begin{array}{l}\text { 1-year PFS, NC;mPFS, } \\
1.3 \text { months }\end{array}$ & $\begin{array}{l}\text { 1-year OS, 2.1\%; } \\
\text { mOS, } 3.1 \text { months }\end{array}$ \\
\hline \multirow[t]{2}{*}{ POPIAR [92] } & \multirow[t]{2}{*}{ Training } & Atezolizumab & \multirow[t]{2}{*}{ H-bTMB $\geq 16$} & \multirow[t]{2}{*}{ NSCLC } & 25 & \multirow[t]{2}{*}{ NA } & ${ }^{*} \mathrm{mPFS}, 4.2$ months & $\begin{array}{l}{ }^{*} \mathrm{mOS}, 13.0 \\
\text { months }\end{array}$ \\
\hline & & Docetaxel & & & 38 & & ${ }^{*} \mathrm{mPFS}, 2.9$ months & ${ }^{*} \mathrm{mOS}, 7.4$ months \\
\hline \multirow[t]{4}{*}{ OAK [92] } & \multirow[t]{4}{*}{ Validation } & Atezolizumab & \multirow[t]{2}{*}{ H-bTMB $\geq 16$} & \multirow[t]{2}{*}{ NSCLC } & 77 & ORR 21\% & \multirow[t]{2}{*}{$\begin{array}{l}\text { *PFS (HR 0.65, 95\% } \\
\text { CI } 0.47-0.92 ; P=0.013)\end{array}$} & $\begin{array}{l}{ }^{*} \mathrm{mOS}, 13.5 \\
\text { months }\end{array}$ \\
\hline & & Docetaxel & & & 81 & ORR 10\% & & ${ }^{*} \mathrm{mOS}, 6.8$ months \\
\hline & & Atezolizumab & \multirow[t]{2}{*}{ bTMB $<16$} & \multirow[t]{2}{*}{ NSCLC } & 216 & ORR 13\% & \multirow{2}{*}{$\begin{array}{l}\text { PFS (HR 0.98, 95\% } \\
\text { CI 0.80-1.2) }\end{array}$} & \multirow{2}{*}{$\begin{array}{l}\text { OS (HR 0.65, 95\% } \\
\text { Cl } 0.52-0.81)\end{array}$} \\
\hline & & Docetaxel & & & 209 & ORR 12\% & & \\
\hline Zhijie W et al. [96] & & $\begin{array}{l}\text { Anti-PD-1/PD- } \\
\text { L1 therapies }\end{array}$ & $\begin{array}{l}\text { bTMB } \geq 6 \\
\text { bTMB }<6\end{array}$ & NSCLC & $\begin{array}{l}28 \\
22\end{array}$ & $\begin{array}{l}\text { *ORR 39.3\% } \\
\text { *ORR } 9.1 \%\end{array}$ & $\begin{array}{l}{ }^{*} \text { mPFS: NR } \\
{ }^{*} \text { mPFS, } 2.9 \text { months }\end{array}$ & \\
\hline
\end{tabular}

Abbreviations: $N$ number, ICBs immune checkpoint blockades, PD-L1 programmed death ligand 1, PD-1 programmed death-1, CTLA-4 cytotoxic T lymphocyte antigen-4, mAb monoclonal antibody, NSCLC non-small cell lung cancer, SCLC small-cell lung cancer, $C T$ chemotherapy, ORR objective response rate, DoR duration of response, PFS progression-free survival, mPFS median progression-free survival, $O S$ overall survival, mOS median overall survival, TMB tumor mutation burden, $H$ high, $M$ medium, $L$ low, $b T M B$ blood-based tumor mutation burden, mut mutation, mut/Mb mutation per megabase, Ref reference, vs versus, $N R$ not reached, $N A$ not available

*Denotes the difference was statistically significant 
expression [88, 97, 98]. Rizvi $\mathrm{H}$ et al. indicated that there was no correlation between PD-L1 and TMB status in patients with NSCLC treated with ICB $(r=0.1915, P=$ 0.08 ). Patients with high-TMB and positive PD-L1 expression had the highest rate of durable clinical benefit than that with only one or neither variable presence (50\% vs. $18.2-35.5 \%$ ) [98]. Fabrizio DA et al. demonstrated that $99.7 \%$ of CRC patients with MSI-H had high TMB status (6.3-746.9 mut/Mb); meanwhile, $97.0 \%$ of CRC patients with MSS were low TMB (0.0-10.8 mut/ $\mathrm{Mb})$ in a large population. Although there was a high consistency between MSI-H and high TMB status in CRC, 2.9\% (163/5702) of patients with MSS were still considered as high TMB [97]. Zachary $\mathrm{R}$ et al. analyzed 100,000 human cancer genomes to reveal the landscape of TMB and found that nearly $83 \%$ of tumor samples with MSI-H showed high TMB status (TMB > 20 mut/ $\mathrm{Mb})$, whereas only $16 \%$ of tumor samples with high TMB was MSI-H and nearly $84 \%$ were classified as MSS [99]. ICB therapy is not recommended for patients with MSI-L/MSS, but these patients might have high TMB and could still benefit from ICB therapy [99]. The cooccurrence of high TMB and MSI-H varied among diverse cancer types, and they usually come together in gastrointestinal cancers, but are rarely consistent in lung cancer or melanoma in which the presence of high TMB is common [99]. Comprehensive analysis of dMMR/ MSI-H, PD-L1, and TMB or a multivariable predictive model composed of 9 exome parameters (the DNA repair pathway status, the WNT pathway status, the number of TCR clones, the number of neoantigens, the HLA*A* 1 and HLA*A*24 status, and the fractions of signatures $1 \mathrm{~A}, 1 \mathrm{~B}$, and 6 ) resulted in greater predictive power and may allow for the optimal usage of ICB therapy $[88,98,100,101]$.

\section{Conclusions and prospects}

Immunotherapy has dramatically changed the therapeutic landscape of multiple tumors and has boosted enthusiasm regarding cancer treatment. Recent positive results from clinical trials of ICB therapies alone or in combination for "difficult-to-treat" dMMR/MSI-H tumors have led to great hope for immunotherapy application in this specific population. dMMR/MSI-H has been approved by the FDA as an indication of ICB for metastatic cancers, irrespective of the cancer types, presumably due to the enhanced immune response through the presence of increased somatic mutations and "nonself" neoantigens in these tumors. The novel use of ICB therapies as first-line or neoadjuvant treatments in dMMR/ MSI-H tumors may have the potential to expand the indications. dMMR/MSI-H has its unique advantages compared with PD-L1, TMB, TILs, and other new predictors. Despite encouraging results of ICB by recognizing $\mathrm{dMMR} / \mathrm{MSI}-\mathrm{H}$, only a fraction of patients typically have the dMMR/MSI-H features, and some sensitive patients still cannot be distinguished. Comprehensive analysis of multiple markers will provide the optimal strategy to identify sensitive patients to ICB therapy in the near future.

\section{Additional files}

Additional file 1: Figure S1. Statistically significant survival analysis of different tumors between the dMMR group and the pMMR group. (PPTX $379 \mathrm{~kb}$ )

Additional file 2: Figure S2. Survival analysis of tumors with or without MMR gene alterations. (PPTX $2269 \mathrm{~kb}$ )

\section{Acknowledgements}

Not applicable.

Authors' contributions

QL contributed to the design of the review and revised the article, had full access to all of the contents included in this review, and took responsibility for the integrity of the data. PFZ wrote the main manuscript text, LL prepared figures and tables, and XYJ provided the guide of immune knowledge and wrote a part of the manuscript. All authors agreed to be accountable for the content of this paper. All authors read and approved the final manuscript.

\section{Funding}

This study is funded by the National Natural Science Foundation of China (Grant NO. 81301912), Beijing Municipal Health System High-level Health Person Foundation Project (Grant NO. 2014-3-005), the Beijing Municipal Science and Technology Commission Foundation (Capital Features, Z161100000516083, to Qin Li), and Natural Science Foundation of Capital Medical University (to Qin Li).

\section{Availability of data and materials \\ Not applicable.}

Ethics approval and consent to participate

Not applicable.

Consent for publication

Not applicable.

Competing interests

The authors declare that they have no competing interests.

\section{Author details}

'Department of Radiotherapy, Beijing Friendship Hospital, Capital Medical University, Beijing 100050, China. '2Department of Oncology, Beijing Friendship Hospital, Capital Medical University, Beijing 100050, China.

Received: 23 December 2018 Accepted: 10 May 2019

Published online: 31 May 2019

\section{References}

1. Brahmer J, Reckamp KL, Baas P, Crinò L, Eberhardt WE, Poddubskaya E, et al. Nivolumab versus docetaxel in advanced squamous-cell non-small-cell lung cancer. N Engl J Med. 2015;373(2):123-35.

2. Robert C, Thomas L, Bondarenko I, O'Day S, Weber J, Garbe C, et al. Ipilimumab plus dacarbazine for previously untreated metastatic melanoma. N Engl J Med. 2011;364(26):2517-26.

3. Apolo AB, Infante JR, Balmanoukian A, Patel MR, Wang D, Kelly K, et al. Avelumab, an anti-programmed death-ligand 1 antibody, in patients with refractory metastatic urothelial carcinoma: results from a multicenter, phase Ib study. J Clin Oncol. 2017;35(19):2117-24. 
4. Powles T, Eder JP, Fine GD, Braiteh FS, Loriot Y, Cruz C, et al. MPDL3280A (anti-PD-L1) treatment leads to clinical activity in metastatic bladder cancer. Nature. 2014;515(7528):558-62.

5. Ansell SM, Lesokhin AM, Borrello I, Halwani A, Scott EC, Gutierrez M, et al. PD-1 blockade with nivolumab in relapsed or refractory Hodgkin's lymphoma. N Engl J Med. 2015;372(4):311-9.

6. Kaufman HL, Russell J, Hamid O, Bhatia S, Terheyden P, D'Angelo SP, et al. Avelumab in patients with chemotherapy-refractory metastatic Merkel cell carcinoma: a multicentre, single-group, open-label, phase 2 trial. Lancet Oncol. 2016;17(10):1374-85.

7. Yi M, Jiao D, Xu H, Liu Q, Zhao W, Han X, et al. Biomarkers for predicting efficacy of PD-1/PD-L1 inhibitors. Mol Cancer. 2018;17(1):129.

8. Lemery S, Keegan P, Pazdur R. First FDA approval agnostic of cancer site when a biomarker defines the indication. N Engl J Med. 2017;377(15):1409-12.

9. Takamochi K, Takahashi F, Suehara Y, Sato E, Kohsaka S, Hayashi T, et al. DNA mismatch repair deficiency in surgically resected lung adenocarcinoma: microsatellite instability analysis using the Promega panel. Lung Cancer. 2017;110:26-31.

10. Ionov Y, Peinado MA, Malkhosyan S, Shibata D, Perucho M. Ubiquitous somatic mutations in simple repeated sequences reveal a new mechanism for colonic carcinogenesis. Nature. 1993:363(6429):558-61.

11. Peltomäki $P$, Aaltonen $L A$, Sistonen $P$, Pylkkänen $L$, Mecklin JP, Järvinen $H$, et al. Genetic mapping of a locus predisposing to human colorectal cancer. Science. 1993;260(5109):810-2.

12. Thibodeau SN, Bren G, Schaid D. Microsatellite instability in cancer of the proximal colon. Science. 1993;260(5109):816-9.

13. Nilbert M, Planck M, Fernebro E, Borg A, Johnson A. Microsatellite instability is rare in rectal carcinomas and signifies hereditary cancer. Eur I Cancer. 1999;35(6):942-5

14. GeneReviews ${ }^{\oplus}$. Seattle (WA): University of Washington, Seattle;1993.

15. Hitchins MP, Ward RL. Constitutional (germline) MLH1 epimutation as an aetiological mechanism for hereditary non-polyposis colorectal cancer. J Med Genet. 2009;46(12):793-802

16. Plazzer JP, Sijmons RH, Woods MO, Peltomäki P, Thompson B, Den DJT, et al. The InSiGHT database: utilizing 100 years of insights into Lynch syndrome. Fam Cancer. 2013;12(2):175-80

17. Peltomäki P, Vasen H. Mutations associated with HNPCC predisposition -- update of ICG-HNPCC/INSiGHT mutation database. Dis Markers. 2004:20(4-5):269-76.

18. Woods MO, Williams P, Careen A, Edwards L, Bartlett S, McLaughlin JR, et al. A new variant database for mismatch repair genes associated with Lynch syndrome. Hum Mutat. 2007;28(7):669-73.

19. Ligtenberg MJ, Kuiper RP, Chan TL, Goossens M, Hebeda KM, Voorendt M, et al. Heritable somatic methylation and inactivation of $\mathrm{MSH} 2$ in families with Lynch syndrome due to deletion of the 3' exons of TACSTD1. Nat Genet. 2009:41(1):112-7.

20. Huth C, Kloor M, Voigt AY, Bozukova G, Evers C, Gaspar H, et al. The molecular basis of EPCAM expression loss in Lynch syndrome-associated tumors. Mod Pathol. 2012;25(6):911-6.

21. Boland CR, Goel A. Microsatellite instability in colorectal cancer. Gastroenterology. 2010;138(6):2073-87 e3.

22. Lynch $\mathrm{HT}$, de la Chapelle A. Hereditary colorectal cancer. N Engl J Med. 2003;348(10):919-32.

23. Yamamoto $\mathrm{H}$, Imai $\mathrm{K}$, Perucho $\mathrm{M}$. Gastrointestinal cancer of the microsatellite mutator phenotype pathway. J Gastroenterol. 2002;37(3):153-63.

24. Cicek MS, Lindor NM, Gallinger S, Bapat B, Hopper JL, Jenkins MA, et al. Quality assessment and correlation of microsatellite instability and immunohistochemical markers among population- and clinic-based colorectal tumors results from the Colon Cancer Family Registry. J Mol Diagn. 2011;13(3):271-81.

25. Kato M, Takano M, Miyamoto M, Sasaki N, Goto T, Tsuda H, et al. DNA mismatch repair-related protein loss as a prognostic factor in endometrial cancers. J Gynecol Oncol. 2015;26(1):40-5.

26. Mills AM, Dill EA, Moskaluk CA, Dziegielewski J, Bullock TN, Dillon PM. The relationship between mismatch repair deficiency and PD-L1 expression in breast carcinoma. Am J Surg Pathol. 2018;42(2):183-91.

27. Ryan S, Jenkins MA, Win AK. Risk of prostate cancer in Lynch syndrome: a systematic review and meta-analysis. Cancer Epidemiol Biomarkers Prev. 2014;23(3):437-49

28. Hause RJ, Pritchard CC, Shendure J, Salipante SJ. Classification and characterization of microsatellite instability across 18 cancer types. Nat Med. 2016;22(11):1342-50
29. Bonneville R, Krook MA, Kautto EA, Miya J, Wing MR, Chen HZ, et al. Landscape of microsatellite instability across 39 cancer types. JCO Precis Oncol. 2017;2017.

30. Le DT, Durham JN, Smith KN, Wang H, Bartlett BR, Aulakh LK, et al. Mismatch repair deficiency predicts response of solid tumors to PD-1 blockade. Science. 2017;357(6349):409-13.

31. Venderbosch S, Nagtegaal ID, Maughan TS, Smith CG, Cheadle JP, Fisher D, et al. Mismatch repair status and BRAF mutation status in metastatic colorectal cancer patients: a pooled analysis of the CAIRO, CAIRO2, COIN, and FOCUS studies. Clin Cancer Res. 2014;20(20):5322-30.

32. Sinicrope FA, Rego RL, Foster N, Sargent DJ, Windschitl HE, Burgart LJ, et al. Microsatellite instability accounts for tumor site-related differences in clinicopathologic variables and prognosis in human colon cancers. Am J Gastroenterol. 2006;101(12):2818-25.

33. Ribic CM, Sargent DJ, Moore MJ, Thibodeau SN, French AJ, Goldberg RM, et al. Tumor microsatellite-instability status as a predictor of benefit from fluorouracilbased adjuvant chemotherapy for colon cancer. N Engl J Med. 2003;349(3):247-57.

34. Guastadisegni C, Colafranceschi M, Ottini L, Dogliotti E. Microsatellite instability as a marker of prognosis and response to therapy: a meta-analysis of colorectal cancer survival data. Eur J Cancer. 2010;46(15):2788-98.

35. Sargent DJ, Marsoni S, Monges G, Thibodeau SN, Labianca R, Hamilton SR, et al. Defective mismatch repair as a predictive marker for lack of efficacy of fluorouracilbased adjuvant therapy in colon cancer. J Clin Oncol. 2010;28(20):3219-26.

36. Jin Z, Sanhueza CT, Johnson B, Nagorney DM, Larson DW, Mara KC, et al. Outcome of mismatch repair-deficient metastatic colorectal cancer: The Mayo Clinic Experience. Oncologist. 2018.

37. Zaanan A, Cuilliere-Dartigues P, Guilloux A, Parc Y, Louvet C, de Gramont A, et al. Impact of p53 expression and microsatellite instability on stage III colon cancer disease-free survival in patients treated by 5-fluorouracil and leucovorin with or without oxaliplatin. Ann Oncol. 2010;21(4):772-80.

38. Kim ST, Lee J, Park SH, Park JO, Lim HY, Kang WK, et al. The effect of DNA mismatch repair (MMR) status on oxaliplatin-based first-line chemotherapy as in recurrent or metastatic colon cancer. Med Oncol. 2010;27(4):1277-85.

39. Bertagnolli MM, Niedzwiecki D, Compton CC, Hahn HP, Hall M, Damas B, et al. Microsatellite instability predicts improved response to adjuvant therapy with irinotecan, fluorouracil, and leucovorin in stage III colon cancer: Cancer and Leukemia Group B Protocol 89803. J Clin Oncol. 2009;27(11):1814-21.

40. Roth AD, Tejpar S, Delorenzi M, Yan P, Fiocca R, Klingbiel D, et al. Prognostic role of KRAS and BRAF in stage II and III resected colon cancer: results of the translational study on the PETACC-3, EORTC 40993, SAKK 60-00 trial. J Clin Oncol. 2010;28(3):466-74.

41. Cunningham JM, Kim CY, Christensen ER, Tester DJ, Parc Y, Burgart LJ, et al. The frequency of hereditary defective mismatch repair in a prospective series of unselected colorectal carcinomas. Am J Hum Genet. 2001;69(4):780-90.

42. Matthews KS, Estes JM, Conner MG, Manne U, Whitworth JM, Huh WK, et al. Lynch syndrome in women less than 50 years of age with endometrial cancer. Obstet Gynecol. 2008;111(5):1161-6.

43. Ruiz I, Martín-Arruti M, Lopez-Lopez E, Garcia-Orad A. Lack of association between deficient mismatch repair expression and outcome in endometrial carcinomas of the endometrioid type. Gynecol Oncol. 2014;134(1):20-3.

44. Nelson GS, Pink A, Lee $S$, Han G, Morris D, Ogilvie T, et al. MMR deficiency is common in high-grade endometrioid carcinomas and is associated with an unfavorable outcome. Gynecol Oncol. 2013;131(2):309-14.

45. Diaz-Padilla I, Romero N, Amir E, Matias-Guiu X, Vilar E, Muggia F, et al. Mismatch repair status and clinical outcome in endometrial cancer: a systematic review and meta-analysis. Crit Rev Oncol Hematol. 2013;88(1):154-67.

46. Xiao X, Melton DW, Gourley C. Mismatch repair deficiency in ovarian cancer -- molecular characteristics and clinical implications. Gynecol Oncol. 2014; 132(2):506-12.

47. Catasús L, Bussaglia E, Rodrguez I, Gallardo A, Pons C, Irving JA, et al. Molecular genetic alterations in endometrioid carcinomas of the ovary: similar frequency of beta-catenin abnormalities but lower rate of microsatellite instability and PTEN alterations than in uterine endometrioid carcinomas. Hum Pathol. 2004;35(11):1360-8.

48. Gras E, Catasus L, Argüelles R, Moreno-Bueno G, Palacios J, Gamallo C, et al. Microsatellite instability, MLH-1 promoter hypermethylation, and frameshift mutations at coding mononucleotide repeat microsatellites in ovarian tumors. Cancer. 2001;92(11):2829-36.

49. Taube JM, Klein A, Brahmer JR, Xu H, Pan X, Kim JH, et al. Association of PD1, PD-1 ligands, and other features of the tumor immune 
microenvironment with response to anti-PD-1 therapy. Clin Cancer Res. 2014;20(19):5064-74.

50. Zhai QJ, Rosen DG, Lu K, Liu J. Loss of DNA mismatch repair protein hMSH6 in ovarian cancer is histotype-specific. Int J Clin Exp Pathol. 2008;1(6):502-9.

51. Ercoli A, Ferrandina G, Raspaglio G, Marone M, Maggiano N, Del MP, et al. hMSH2 and GTBP expression in advanced stage epithelial ovarian cancer. $\mathrm{Br}$ J Cancer. 1999;80(10):1665-71.

52. Beghelli S, de Manzoni G, Barbi S, Tomezzoli A, Roviello F, Di GC, et al. Microsatellite instability in gastric cancer is associated with better prognosis in only stage II cancers. Surgery. 2006;139(3):347-56.

53. Fang WL, Chang SC, Lan YT, Huang KH, Chen JH, Lo SS, et al. Microsatellite instability is associated with a better prognosis for gastric cancer patients after curative surgery. World J Surg. 2012;36(9):2131-8.

54. An JY, Kim H, Cheong JH, Hyung WJ, Kim H, Noh SH. Microsatellite instability in sporadic gastric cancer: its prognostic role and guidance for 5FU based chemotherapy after R0 resection. Int J Cancer. 2012;131(2):505-11.

55. Oki E, Kakeji Y, Zhao Y, Yoshida R, Ando K, Masuda T, et al. Chemosensitivity and survival in gastric cancer patients with microsatellite instability. Ann Surg Oncol. 2009;16(9):2510-5.

56. Alvino E, Passarelli F, Cannavò E, Fortes C, Mastroeni S, Caporali S, et al. High expression of the mismatch repair protein MSH6 is associated with poor patient survival in melanoma. Am J Clin Pathol. 2014;142(1):121-32.

57. Topalian SL, Sznol M, McDermott DF, Kluger HM, Carvajal RD, Sharfman WH, et al. Survival, durable tumor remission, and long-term safety in patients with advanced melanoma receiving nivolumab. J Clin Oncol. 2014;32(10):1020-30.

58. Hodi FS, O'Day SJ, McDermott DF, Weber RW, Sosman JA, Haanen JB, et al. Improved survival with ipilimumab in patients with metastatic melanoma. $\mathrm{N}$ Engl J Med. 2010;363(8):711-23.

59. Herbst RS, Soria JC, Kowanetz M, Fine GD, Hamid O, Gordon MS, et al. Predictive correlates of response to the anti-PD-L1 antibody MPDL3280A in cancer patients. Nature. 2014:515(7528):563-7.

60. Garon EB, Rizvi NA, Hui R, Leighl N, Balmanoukian AS, Eder JP, et al. Pembrolizumab for the treatment of non-small-cell lung cancer. N Engl J Med. 2015;372(21):2018-28.

61. Reck M, Rodríguez-Abreu D, Robinson AG, Hui R, Csőszi T, Fülöp A, et al. Pembrolizumab versus chemotherapy for PD-L1-positive non-small-cell lung cancer. N Engl J Med. 2016;375(19):1823-33.

62. Gulley JL, Rajan A, Spigel DR, lannotti N, Chandler J, DJL W, et al. Avelumab for patients with previously treated metastatic or recurrent non-small-cell lung cancer (JAVELIN Solid Tumor): dose-expansion cohort of a multicentre, open-label, phase 1b trial. Lancet Oncol. 2017;18(5):599-610.

63. Massard C, Gordon MS, Sharma S, Rafii S, Wainberg ZA, Luke J, et al. Safety and efficacy of durvalumab (MED|4736), an anti-programmed cell death ligand-1 immune checkpoint inhibitor, in patients with advanced urothelial bladder cancer. J Clin Oncol. 2016;34(26):3119-25.

64. Marcus L, Lemery SJ, Keegan P, Pazdur R. FDA approval summary: pembrolizumab for the treatment of microsatellite instability-high solid tumors. Clin Cancer Res. 2019.

65. Le DT, Uram JN, Wang H, Bartlett BR, Kemberling H, Eyring AD, et al. PD-1 blockade in tumors with mismatch-repair deficiency. N Engl J Med. 2015; 372(26):2509-20.

66. Diaz LA, Marabelle A, Kim T, et al. Efficacy of pembrolizumab in phase 2 KEYNOTE-164 and KEYNOTE-158 studies of microsatellite instability high cancers. Ann Oncol. 2017;(suppl 5):abstr 386P.

67. Le D, Kavan P, Kim T, et al. Safety and antitumor activity of pembrolizumab in patients with advanced microsatellite instability-high (MSI-H) colorectal cancer: KEYNOTE-164. Ann Oncol. 2018;29(suppl 5):abstr 0-021.

68. Overman MJ, McDermott R, Leach JL, Lonardi S, Lenz HJ, Morse MA, et al. Nivolumab in patients with metastatic DNA mismatch repair-deficient or microsatellite instability-high colorectal cancer (CheckMate 142): an openlabel, multicentre, phase 2 study. Lancet Oncol. 2017;18(9):1182-91.

69. Antonia SJ, López-Martin JA, Bendell J, Ott PA, Taylor M, Eder JP, et al. Nivolumab alone and nivolumab plus ipilimumab in recurrent small-cell lung cancer (CheckMate 032): a multicentre, open-label, phase 1/2 trial. Lancet Oncol. 2016;17(7):883-95.

70. Larkin J, Chiarion-Sileni V, Gonzalez R, Grob JJ, Cowey CL, Lao CD, et al. Combined nivolumab and ipilimumab or monotherapy in untreated melanoma. N Engl J Med. 2015;373(1):23-34.

71. Overman MJ, Lonardi S, KYM W, Lenz HJ, Gelsomino F, Aglietta M, et al. Durable clinical benefit with nivolumab plus ipilimumab in DNA mismatch repair-deficient/microsatellite instability-high metastatic colorectal cancer. J Clin Oncol. 2018;36(8):773-9.

72. Lenz HJ, van Cutsem E, Limon ML, Wong KY, Hendlisz A, Aglietta M, et al. Durable clinical benefit with nivolumab (NIVO) plus low-dose ipilimumab (IPI) as first-line therapy in microsatellite instability-high/mismatch repair deficient (MSI-H/dMMR) metastatic colorectal cancer (mCRC). Annals of Oncology. 2018;29(suppl 8):abstr LBA18.

73. Chalabi M, Fanchi LF, Van den Berg JG, Beets GL, Lopez-Yurda M, Aalbers $A G$, et al. Neoadjuvant ipilimumab plus nivolumab in early stage colon cancer. Ann Oncol. 2018;29(suppl 8):abstr LBA37.

74. Gatalica Z, Snyder C, Maney T, Ghazalpour A, Holterman DA, Xiao N, et al. Programmed cell death 1 (PD-1) and its ligand (PD-L1) in common cancers and their correlation with molecular cancer type. Cancer Epidemiol Biomarkers Prev. 2014;23(12):2965-70.

75. Balar AV, Castellano D, O'Donnell PH, Grivas P, Vuky J, Powles T, et al. Firstline pembrolizumab in cisplatin-ineligible patients with locally advanced and unresectable or metastatic urothelial cancer (KEYNOTE-052): a multicentre, single-arm, phase 2 study. Lancet Oncol. 2017;18(11):1483-92.

76. Bauml J, Seiwert TY, Pfister DG, Worden F, Liu SV, Gilbert J, et al. Pembrolizumab for platinum- and cetuximab-refractory head and neck cancer: results from a single-arm, phase II study. J Clin Oncol. 2017;35(14):1542-9.

77. Hui R, Garon EB, Goldman JW, Leighl NB, Hellmann MD, Patnaik A, et al. Pembrolizumab as first-line therapy for patients with PD-L1-positive advanced non-small cell lung cancer: a phase 1 trial. Ann Oncol. 2017;28(4):874-81.

78. Daud Al, Wolchok JD, Robert C, Hwu WJ, Weber JS, Ribas A, et al. Programmed death-ligand 1 expression and response to the antiprogrammed death 1 antibody pembrolizumab in melanoma. J Clin Oncol. 2016;34(34):4102-9.

79. National Comprehensive Cancer Network (NCCN) Clinical Practice Guidelines in Oncology: Head and Neck Cancers Version 1.2019. https://www.nccn.org/ professionals/physician_gls/default.aspx\#site. Accessed 6 Mar 2019.

80. National Comprehensive Cancer Network (NCCN) Clinical Practice Guidelines in Oncology: Non-Small Cell Lung Cancer, Version 1.2019. https://www.nccn.org/ professionals/physician_gls/default.aspx\#site. Accessed 19 Oct 2018.

81. Rizvi NA, Hellmann MD, Snyder A, Kvistborg P, Makarov V, Havel JJ, et al. Cancer immunology. Mutational landscape determines sensitivity to PD-1 blockade in non-small cell lung cancer. Science. 2015;348(6230): $124-8$.

82. Kim ST, Klempner SJ, Park SH, Park JO, Park YS, Lim HY, et al. Correlating programmed death ligand 1 (PD-L1) expression, mismatch repair deficiency, and outcomes across tumor types: implications for immunotherapy. Oncotarget. 2017:8(44):77415-23.

83. Inaguma S, Wang Z, Lasota J, Sarlomo-Rikala M, McCue PA, Ikeda H, et al. Comprehensive immunohistochemical study of programmed cell death ligand 1 (PD-L1): analysis in 5536 cases revealed consistent expression in trophoblastic tumors. Am J Surg Pathol. 2016;40(8):1133-42.

84. Wang L, Zhang Q, Ni S, Tan C, Cai X, Huang D, et al. Programmed deathligand 1 expression in gastric cancer: correlation with mismatch repair deficiency and HER2-negative status. Cancer Med. 2018;7(6):2612-20.

85. Lee SJ, Jun SY, Lee IH, Kang BW, Park SY, Kim HJ, et al. CD274, LAG3, and IDO1 expressions in tumor-infiltrating immune cells as prognostic biomarker for patients with MSI-high colon cancer. J Cancer Res Clin Oncol. 2018; 144(6):1005-14.

86. Llosa NJ, Cruise M, Tam A, Wicks EC, Hechenbleikner EM, Taube JM, et al. The vigorous immune microenvironment of microsatellite instable colon cancer is balanced by multiple counter-inhibitory checkpoints. Cancer Discov. 2015;5(1):43-51.

87. Topalian SL, Drake CG, Pardoll DM. Immune checkpoint blockade: a common denominator approach to cancer therapy. Cancer Cell. 2015;27(4):450-61.

88. Carbone DP, Reck M, Paz-Ares L, Creelan B, Horn L, Steins M, et al. First-line nivolumab in stage IV or recurrent non-small-cell lung cancer. N Engl J Med. 2017:376(25):2415-26.

89. Ramalingam SS, Hellmann MD, Awad MM, et al. Tumor mutation burden (TMB) as a biomarker for clinical benefit from dual immune checkpoint blockade with nivolumab (nivo) + ipilimumab (ipi) in first-line (1 L) nonsmall cell lung cancer (NSCLC): identification of TMB cutoff from CheckMate 568. In: Presented at the American Association for Cancer Research 2018 Annual Meeting: 2018, abstr (T078).

90. Hellmann MD, Ciuleanu TE, Pluzanski A, Lee JS, Otterson GA, AudigierValette $C_{\text {, }}$ et al. Nivolumab plus ipilimumab in lung cancer with a high tumor mutational burden. N Engl J Med. 2018a;378(22):2093-104. 
91. Hellmann MD, Callahan MK, Awad MM, Calvo E, Ascierto PA, Atmaca A, et al. Tumor mutational burden and efficacy of nivolumab monotherapy and in combination with ipilimumab in small-cell lung cancer. Cancer Cell. 2018b;33(5):853-61 e4.

92. Gandara DR, Paul SM, Kowanetz M, Schleifman E, Zou W, Li Y, et al. Bloodbased tumor mutational burden as a predictor of clinical benefit in nonsmall-cell lung cancer patients treated with atezolizumab. Nat Med. 2018; 24(9):1441-8.

93. Hugo W, Zaretsky JM, Sun L, Song C, Moreno BH, Hu-Lieskovan S, et al. Genomic and transcriptomic features of response to anti-PD-1 therapy in metastatic melanoma. Cell. 2016;165(1):35-44.

94. Rosenberg JE, Hoffman-Censits J, Powles T, van der Heijden MS, Balar AV, Necchi A, et al. Atezolizumab in patients with locally advanced and metastatic urothelial carcinoma who have progressed following treatment with platinum-based chemotherapy: a single-arm, multicentre, phase 2 trial. Lancet. 2016;387(10031):1909-20.

95. Samstein RM, Lee CH, Shoushtari AN, Hellmann MD, Shen R, Janjigian YY, et al. Tumor mutational load predicts survival after immunotherapy across multiple cancer types. Nat Genet. 2019;51(2):202-6.

96. Wang Z, Duan J, Cai S, Han M, Dong H, Zhao J, et al. Assessment of blood tumor mutational burden as a potential biomarker for immunotherapy in patients with non-small cell lung cancer with use of a next-generation sequencing cancer gene panel. JAMA Oncol. 2019

97. Fabrizio DA, George TJ, Dunne RF, Frampton G, Sun J, Gowen K, et al. Beyond microsatellite testing: assessment of tumor mutational burden identifies subsets of colorectal cancer who may respond to immune checkpoint inhibition. J Gastrointest Oncol. 2018;9(4):610-7.

98. Rizvi H, Sanchez-Vega F, La K, Chatila W, Jonsson P, Halpenny D, et al. Molecular determinants of response to anti-programmed cell death (PD)-1 and anti-programmed death-ligand 1 (PD-L1) blockade in patients with non-small-cell lung cancer profiled with targeted next-generation sequencing. J Clin Oncol. 2018;36(7):633-41.

99. Chalmers ZR, Connelly CF, Fabrizio D, Gay L, Ali SM, Ennis R, et al. Analysis of 100,000 human cancer genomes reveals the landscape of tumor mutational burden. Genome Med. 2017:9(1):34

100. Richard C, Fumet JD, Chevrier S, Derangère $V$, Ledys F, Lagrange $A$, et al. Exome analysis reveals genomic markers associated with better efficacy of nivolumab in lung cancer patients. Clin Cancer Res. 2018.

101. Yarchoan M, Hopkins A, Jaffee EM. Tumor mutational burden and response rate to PD-1 inhibition. N Engl J Med. 2017;377(25):2500-1.

\section{Publisher's Note}

Springer Nature remains neutral with regard to jurisdictional claims in published maps and institutional affiliations.

Ready to submit your research? Choose BMC and benefit from:

- fast, convenient online submission

- thorough peer review by experienced researchers in your field

- rapid publication on acceptance

- support for research data, including large and complex data types

- gold Open Access which fosters wider collaboration and increased citations

- maximum visibility for your research: over $100 \mathrm{M}$ website views per year

At $\mathrm{BMC}$, research is always in progress.

Learn more biomedcentral.com/submissions 